(C) Makarova O.M.

UDC 616.314-089.23.87-071

DOI https://doi.org/10.31718/mep.2019.23.3-4.04

\title{
DIAGNOSTIC CRTITERIA OF ORTHODONTIC TREATMENT WITH EXTRACTION OF SOME TEETH
}

Makarova O.M.

Ukrainian Medical Stomatological Academy, Poltava, Ukraine

Orthodontic treatment for adults is always difficult process, which requires morphological, functional, aesthetic factors and limited possibilities of dentoalveolar teeth positioning. One of the most actual issues of orthodontic correction in adults is teeth extractions by orthodontic. Nowadays, when there is a concept of «arch development», skeletal enlargement and miniimplants, treatment with extraction should be correctly explained and determined by orthodontic treatment and should not be caused to functional status and face aesthetics, which provides qualitative and stabile result of treatment. Besides, necessity of teeth extraction of some teeth which are written in medical protocol, secures a doctor from law risks. The aim of the investigation was to establish correlative link between parameters of morphometric analysis of control and diagnostic models of jaws by Snagina and roentgenologic parameters of lateral cephalometry by Kim. Adult patients aged from 18 to 32 years old (50) by the $1^{\text {st }}$ class of dentofacial abnormalities and the degree of teeth crowding were involved in the investigation. Results. Indications to treatment with teeth extraction by skeletal and dentoalveolar parameters are different, although there is connection between skeletal parameters and the width of apical basis of maxilla. Skeletal and dentoalveolar morphometric parameters that are used for evaluation of extraction necessity of some teeth and planning for orthodontic treatment is always individual. Done correlation analysis determined that single parameter of apical basis that correlates with CF is its width on the maxilla. CF has direct correlative connection of midline ( $r=0.52)$ with width of apical basis. Skeletal diagnosis and facial aesthetics is leading factor in modern orthodontics. During treatment plan one should orient into aesthetic and functional prognosis, structure of facial skeleton, and after that dentoalveolar parameters.

Key words: orthodontic treatment, dental extraction, morphometry, teleroentgenography.

Планування ортодонтичного лікування дорослих - це завжди складний процес, що потребує врахування великої кількості морфологічних, функціональних та естетичних факторів і розуміння меж та «вичерпності» можливостей дентоальвеолярного переміщення зубів. Одним з найбільш актуальних питань ортодонтичної корекції у дорослих $є$ видалення зубів за ортодонтичним показаннями з метою створення місця та корекції невідповідності верхнього та нижнього зубних рядів. На сьогоднішній день, коли існують концепція «аrch development», скелетне розширення та мініімпланти, лікування з екстракцією має бути чітко аргументоване ортодонтичними показаннями, не призводити до погіршення функціонального стану та естетики обличчя, що забезпечить якісний та стабільний результат лікування. Крім того, протокольно доведена на основі об'єктивних методів обстеження необхідність видалення окремих зубів убезпечить лікаряортодонта від юридичних ризиків. Метою дослідження було встановити чи є кореляційний зв'язок параметрів морфометричного аналізу контрольно-діагностичних моделей щелеп за Снагіною та рентгенологічних параметрів бічної ТРГ за Кіm. Об'єктом дослідження були дорослі пацієнти віком від 18 до 32 років (50) із I класом ЗЩА (дентоальвеолярним та скелетним) та різним ступенем скупченості зубів. Показання до лікування з видаленням зубів за скелетними та дентоальвеолярними параметрами розбігаються, хоч і простежується деяка закономірність (залежність) між скелетними параметрами та шириною апікального базису верхньої щелепи, з чого випливає ряд висновків: скелетні та дентоальвеолярні морфометричні параметри, що використовуються для оцінки необхідності видалення окремих зубів іноді протиречат одни одному, тому планування ортодонтичного лікування завжди $\epsilon$ індивідуальним. Проведений кореляційний аналіз показав, що єдиним параметром апікального базису, що прямо корелює із CF $є$ його ширина на верхній щелепі. CF має прямий кореляційний зв'язок середньої сили (r=0.52) із шириною апікального базису верхньої щелепи. Тобто, чим нижчим був комбінований фактор, тим вужчим був апікальний базис верхньої щелепи. При складанні плану лікування в першу чергу орієнтуватися на естетичний та функціональний прогноз, будову лицевого скелету, а потім - на дентоальвеолярні параметри.

Ключові слова: ортодонтичні лікування, екстракція зубів, морфометрія, телерентгенографія.

\section{Introduction}

Orthodontic treatment for adults is always a difficult process, which requires morphological, functional, aesthetic factors and limited possibilities of dentoalveolar teeth positioning [1,2].

Limited possibilities for orthodontic correction in adults are determined by the widespread use of orthognathic surgery, which is not extensively used in dental practice nowadays. Therefore, the most common method of orthodontic treatment for adults is identified by dentoalveolar correction [3].

One of the most relevant issues of orthodontic correction in adults is teeth extraction by orthodontic indications aimed at creating place and correction of upper and lower dentition.

In orthodontics, it is not feasible to extract teeth when it is not necessary. It is likewise ineligible when they are not extracted when it is necessary.

It should be noted that tooth extraction is a manipula-

To cite this english version Makarova O.M. Diagnostic crtiteria of orthodontic treatment with extraction of some teeth. // The Medical and ecological problems. - 2019. - Vol 23, № 3-4. - P. 13-16. 
tion which can have side effects, complications, and risk factors. Each number of teeth is designed to performing functions and tasks and is responsible for specific role in occlusion function.

Current indications to teeth extraction is the presence of overjet, inadequacy of teeth sizes, bimaxillary protrusion, protrusive profile.

Most often, in the orthodontic practice, the extraction of the first premolars is performed, because they erupt firstly among lateral teeth and their extraction allows canines erupting, because the first premolar is located between frontal and lateral teeth, the place after its removal can be placed for eliminating deficiency in frontal area and lateral one (crowding elimination) and (row boat effect) $[4,5,6,7,8$,$] .$

Orthodontic contraindications to premolars extraction include retroversion of frontal teeth positioning, horizontal type of growth, increase the height of bite, enlarged sizes of tongue. Besides, treatment with extraction of premolars disintegrates the parallel parameters of teeth roots, provides indications for mesio-distal angle and rotation.

During teeth extraction by orthodontic indications, the following factors should be considered: aesthetic (facial profile, incisors explosion, depth of lips, their length, sizes of the nose); morphological (biotype of periodontium, volume of bone tissue, integrity of cortical plate); functional (volume of upper respiratory tracts, tongue position) and also malocclusion $[9,10,11,12]$.

Nowadays, when there is a concept of «arch development», skeletal enlargement and mini-implants, treatment with extraction should be correctly explained and determined by orthodontic treatment and should not be caused to functional status and face aesthetics, which provides qualitative and stabile result of treatment. Besides, necessity of teeth extraction of some teeth which are written in medical protocol, secures a doctor from law risks.

Methods of morphometric and X-ray investigations are widely used to diagnose and determine the necessity of teeth extraction in each patient.

Morphometric method by Snagina allows evaluating the correlation between sizes of basal and dental arches. During place deficiency on the level of basal arch there is teeth protrusion and it deteriorates facial profile, aesthetics of lips and also it affects the condition of alveolar bone in the area of frontal teeth.

Informative method for diagnostics is lateral digital cephalometry, especially Kim analysis, diagnostic value of which is identification of skeletal class of dentofacial abnormality, prognosis of opportunity of bite opening during treatment and evaluation of teeth extraction by skeletal indications.

However, clinical practice determines that results of both methods are not similar and it can complicate the clinical decision and treatment plan.

The aim of the investigation was to establish correlative link between parameters of morphometric analysis of control and diagnostic models of jaws by Snagina and roentgenologic parameters of lateral cephalometry by Kim.

\section{Materials and methods}

Adult patients aged from 18 to 32 years old (50) by the $1^{\text {st }}$ class of dentofacial abnormalities and the degree of teeth crowding were involved in the investigation.

Clinical and lab investigation was done. In the given investigation results of both methods of investigation were analyzed by protocols. Morphometric research by Snagina (determination of width and length of apical basis of jaws) and lateral cephalometry by Kim, especially parameter of Combination Factor, which is calculated by the basis of formula: the angle of palatine and mandibular axis to $\mathrm{FH}$, facial angle and inclination lines A-B to facial area (Fig. 1). [13].

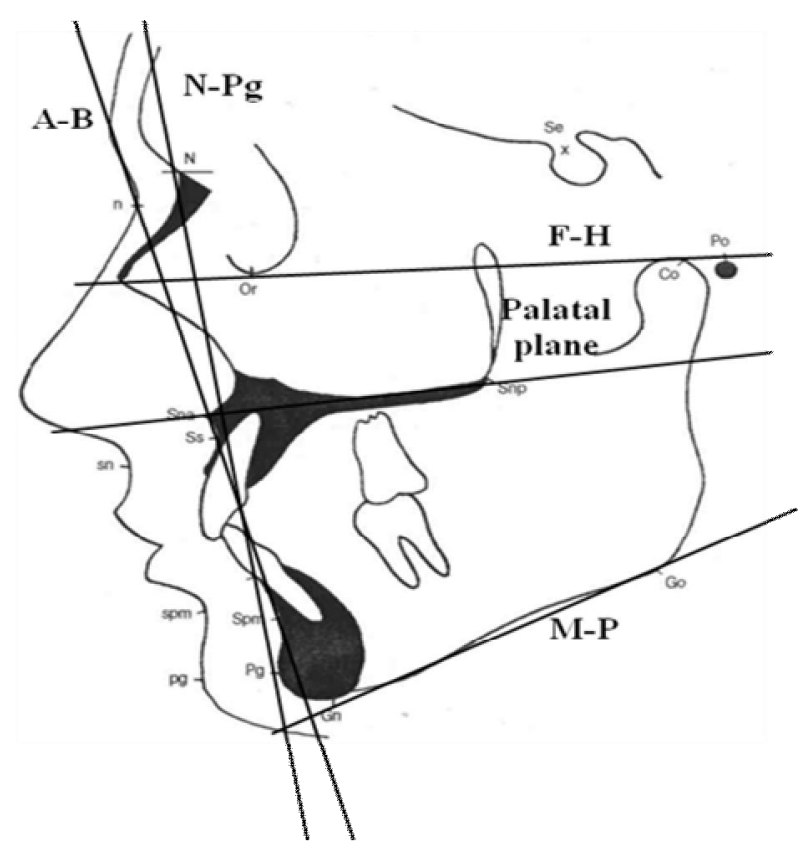

Fig. 1. Schematic analysis of cephalometric analysis by Kim method.

\section{Results}

Morphometric analysis of control and diagnostic models of jaws by Snagina determines 4 parameters: the width of basis of upper jaw, the length of apical basis of upper jaw, the width of apical basis of lower jaw, the length of apical basis of mandible. Each of these parameters can have decrease of the $1^{\text {st }}$ degree (they do not require extraction) and the 2nd degree (this degree indicates the necessity of extraction).

The width of apical basis of upper jaw in average contains $40.4 \pm 3.92 \mathrm{~mm}$, the length $-38.8 \pm 3.04 \mathrm{~mm}$. On the mandible - $34.4 \pm 3.13 \mathrm{~mm}$ and $35.7 \pm 2.28 \mathrm{~mm}$ correspondingly. As a consequence of narrowing of apical basis of maxilla extraction was necessary for 15 patients, shortening - for 14 people. Based on indices of the width of apical basis of mandible extraction was needed for 26 patients, the length - for 25 .

So, adults require extraction due to deficiency of apical basis of mandible which is different from maxilla and it does not require enlargement, and bone tissue and periodontium are the most susceptible during orthodontic correction [14].

CF normally contains $155.9^{\circ}$ and is an indicator of vertical and sagittal skeletal disturbances. If indices of CF is lesser than $155.9^{\circ}$, so skeletal parameters of patient require teeth extraction. The meaning of CF is bigger than $155.9^{\circ}$ indicates favorable prognosis of treatment without teeth extraction and positive aesthetic result.

Average meaning of CF among patients was $158.9 \pm 10.77^{\circ}$. According to $\mathrm{Kim}, 22$ patients required treatment with extraction (CF<155.5).

Among 50 patients, only 4 people did not require extraction. 
24 patients did not require extraction by data of CF, but they had decreased sizes of apical basis by one parameter. Therefore, conclusions on necessity of extraction by data of cephalometric and morphometric analysis were not coincided.

Among patients with high CF (patients who do not require extraction by skeletal parameters), in 2 patients narrowing of apical basis of upper jaw of the second stage is observed, in 10 - shortening of apical basis of the $2^{\text {nd }}$ degree is observed, in 16 patients - narrowing and shortening of apical basis of mandible of the $2^{\text {nd }}$ degree are observed, in 16 - narrowing and shortening of apical basis of mandible of $2^{\text {nd }}$ degree are observed.

Among 23 patients with $C F<155.9$ (they required extraction due to abnormality of skeletal development), only 1 patient presented with normal sizes of apical basis, 13 of them had narrowing of apical basis of maxilla, 4 shortening, in 10 patients narrowing of apical basis of upper jaw is observed, in 11 - shortening.

We analyzed the number of parameters of apical basis which was decreased between two groups. Among patients with normal meaning of CF decrease, one of parameters of apical basis was observed in 5 patients, two - in 13 patients, three parameters - in 2 patients, all four parameters - in nobody of examined patients.

Among patients with low CF, decrease of one parameter is observed in 3 patients, two parameters - in 7 patients, three ones - in 4 patients, all four parameters in 2 patients.

We conducted the correlation analysis and determined that a single parameter of apical basis that correlates with CF is its width on the maxilla. CF has a direct

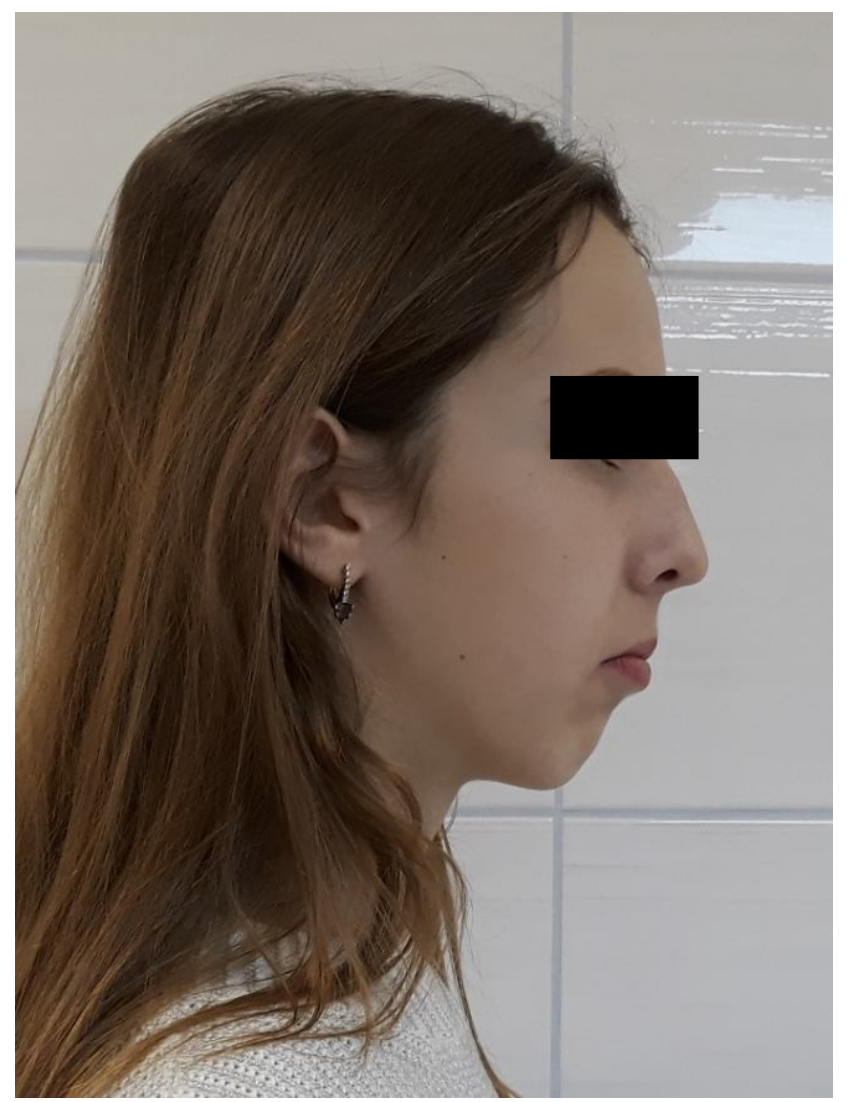

$A$ correlative connection of midline $(r=0.52)$ with width of apical basis. Thus, the lowest factor of the process is observed, the narrowest apical basis of upper jaw is determined.

The revealed fact is quite logical and may be explained by the fact that the upper jaw is the leading in growth and dictates the development of face and both jaws. The transversal hypoplasia of the upper jaw, which is primarily manifested by the narrowing of the upper dentition, is the cause of the formation of various bite anomalies, inadequate growth of the mandible and as a result of the deficit of the place for the teeth.

Let us give a clinical case of a patient K., 19 years old, who presented with complaints of disrupted facial and smile aesthetics. Objectively, the patient has a long face, the lips are tightened, the first class of malocclusion by Angle, palatine position of the upper lateral incisors, protrusion of the upper central incisors, congestion of the lower incisors of the second degree.

According to the morphometry, the patient revealed the II degree of apical basis of the upper jaw narrowing, which involves the extraction of premolars. According to the TRG, the CF was $157.2^{\circ}$, which allowed us to plan treatment without extraction of teeth.

Thus, dental parameters indicated the need for extraction, and skeletal - for the possibility of treatment without extraction. The patient was given an alternative treatment without removing premolars with the use of rapid palatal expansion and multi-loop technique, which allowed eliminating not only the teeth position abnormality of the but also improving the profile of the face (Fig. 2).

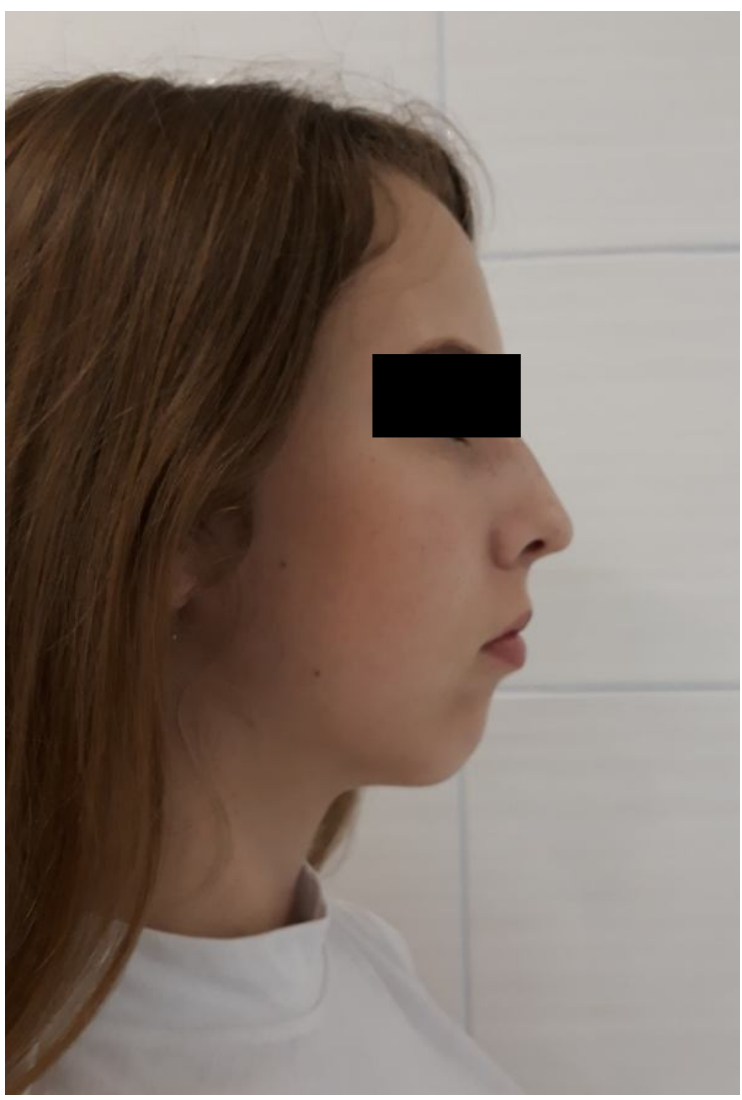

B 


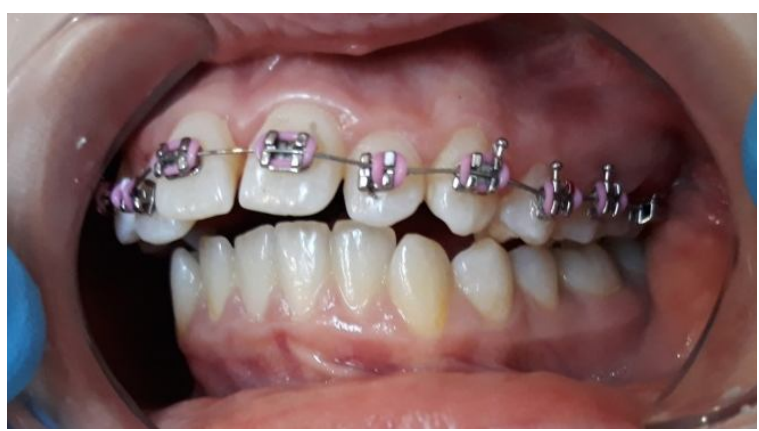

$A$

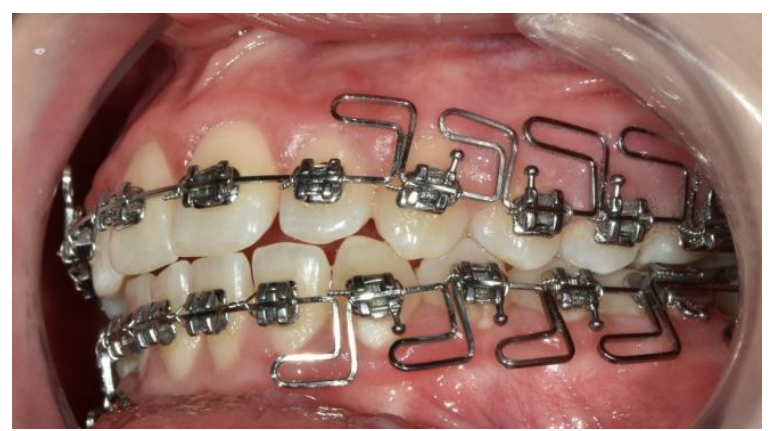

$B$

Fig. 2. Clinical case, patient K., 19 years old:

A - face profile and bite at the initial stage of treatment (braces fixation after palatine expansion); $B$ - facial profile and bite on the main stage of treatment (6 months of orthodontic correction).

Thus, indications to treatment with teeth extraction by skeletal and dentoalveolar parameters are different, although there is connection between skeletal parameters and the width of apical basis of maxilla. Skeletal and dentoalveolar morphometric parameters that are used for evaluation of extraction necessity of some teeth and planning for orthodontic treatment are always individual.

Skeletal diagnosis and facial aesthetics is a leading factor in modern orthodontics. During treatment plan one should orient into aesthetic and functional prognosis, structure of facial skeleton, and after that dentoalveolar parameters.

The prospects for further research include the necessity of additional methods and morphological indicators, aesthetic parameters and functional status of masticatory apparatus should be also considered.

\section{References}

1. Bjering $R$, Midtb M, Birkeland $K$, Vandevska-Radunovic $V$. Stability of non-extraction treatment 10 years out of retention. Materials of the 90 -th Congress of the European Ortodontic Society 2014; 69.

2. Eliseo Palencia. Modelling extraction decision making. Materials of the 88-th Congress of the European Ortodontic Society 2012; 19.

3. Bohater M, Matthews T, Antoszewska J et al. Comparison of Therapy in Adult Subjects with Crowded Anterior Teeth - Single Incisor Expansion, Proclination or Extraction? Materials of the 85-th Congress of the European Ortodontic Society 2009; 49-50.

4. Arun T, Nalbantgil N, Isik F et al. Effect of premolar extractions on the eruption angle of mandibular third molars. Materials of the 82-th Congress of the European Ortodontic Society 2006; 133.

5. Demir Aktop P, Alcan T. Asymmetric premolar extractions in patients with class II subdivision malocclusions: two case reports. Materials of the 88-th Congress of the European Ortodontic Society 2012 June 18-23; 297-298.
6. Cura N, Ozta E, Gill A. Influence of premolar extractions on the position of the lower third molars. Materials of the 75-th Congress of the European Ortodontic Society 1999; 98.

7. Jarrah L, Jarrah $\mathrm{H}$. Evidence based extraction. Materials of the 84-th Congress of the European Ortodontic Society $2008 ; 127$.

8. Kocadereli I, Saysel MY, Meral GD, Tasar F. The effects of fist premolar extractions on third molar angulation. Materials of the 81-st Congress of the European Ortodontic Society 2005; 145.

9. Lodice G, Laino G, Ammendola $L$ et al. The impact of extraction and non-extraction treatment on facial aesthetics and smile attractiveness. Materials of the 88-th Congress of the European Ortodontic Society 2012; 235-236.

10. Lonescu E, Grigore R, Balanescu AM et al. Extraction versus non-extraction: dimensional changes of the dental arches. Materials of the 87-th Congress of the European Ortodontic Society 2011; 373.

11. Maaitah E, Alhaija E, Said N. Effects of first premolar extractions on upper airway dimensions in bimaxillaryproclination patients. Materials of the 88-th Congress of the European Ortodontic Society 2012; 152.

12. Mesaros MF, Muntean A, Rodica $\mathrm{J}$ et al. Criteria used in choosing which teeth to extract for orthodontic purposes. Materials of the 84-th Congress of the European Ortodontic Society 2008; 190.

13. Kim YH, Caulfield Z, Nahm Ch W, Chang YII. Overbite Depth Indicator, Anteroposterior Dysplasia Indicator, Combination Factor and Extraction Index. The International Journal of the Multiloop Edgewise Arch Wire Technic and Research Foundation 1994; 1(1): 81-104.

14. Kuroedova VD, Vyzhenko EE., Makarova AN., Stasiuk AA. Optical density of mandible in orthodontic patients. Wiadomości Lekarskie (Czasopismo Polskiego Towarzystwa Lekarskiego) 2018; LXXI, 6:1161-1164.

Матеріал надійшов до редакції 04.04.2019 